\title{
Retraction Note to: miR-376a inhibits the proliferation and invasion of osteosarcoma by targeting FBX011
}

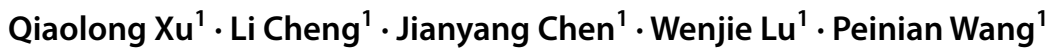

Published online: 18 June 2020

(C) Japan Human Cell Society 2020

\section{Retraction note to:}

Human Cell (2019) 32:390-396

https://doi.org/10.1007/s13577-019-00256-2

This article [1] has been retracted by the editors because the data are unreliable. It appears that the images in Fig. $4 \mathrm{c}$ have been re-used but labelled as different conditions, specifically:

- Part of the panel labelled as J2OS cell line transfected with pcDNA3.1 appears to have been reproduced in the panel labelled as MG63 cells transfected with the same plasmid.

- Part of the panel labelled as J2OS cell line transfected with miR-376a mimic appears to have been re-used in two other panels for si-FBXO11 in both cell lines.

- There appear to be multiple copies of a distinctly shaped cell in the NC-siR panel for MG63 cell line.
The authors were asked to provide raw data for this figure, but were unable to do so. Author Jianyang Chen stated on behalf of all co-authors that they agree to this retraction.

\section{Reference}

1. Xu, Q., Cheng, L., Chen, J. et al. miR-376a inhibits the proliferation and invasion of osteosarcoma by targeting FBXO11. Human Cell 32, 390-396 (2019). https://doi.org/10.1007/s13577-01900256-2

Publisher's Note Springer Nature remains neutral with regard to jurisdictional claims in published maps and institutional affiliations.
The original article can be found online at https://doi.org/10.1007/ s13577-019-00256-2.

Jianyang Chen

dr_chenjianyang@126.com

1 Department of Orthopedic, The People's Hospital of Cixi, No. 999 East Nanerhuan Road, Hushan Street, Cixi 315300, People's Republic of China 